\title{
The Influence of Transformational Leadership on the Performance of Employees with Motivation and Job Satisfaction as Intervening (A Study on the Office of the Department of Irrigation works in the District of Sidoarjo, Indonesia)
}

\author{
Mochammad Munir Rachman Sugijanto Siti Samsyah \\ Lecturer Faculty of Economics and Business University of PGRI Adi Buana Surabaya
}

\begin{abstract}
The aim of this research is to examine the transformational leadership in order to improve employee performance through work motivation and employee satisfaction in order to deliver maximum performance. The study used samples of 161 respondents while sampling techniques using Stratified random sampling or the strata sample were disproportionate with the sampling-based on a number of observable variable indicators. While the analysis uses SEM done through testing instruments with the measurement of the analysis of the Confirmatory factor (CFA). The results of this study show that transformational leadership towards motivation has a positive and significant influence on motivation. Transformational leadership has a positive and significant influence on job satisfaction. Motivation has a negative and insignificant influence on job satisfaction. Motivation has a positive and significant influence on employee performance. Job satisfaction has a positive and significant influence on employee performance. Transformational leadership has a positive and insignificant influence on employee performance. Transformational leadership towards employee satisfaction through motivation has a negative and insignificant influence. Transformational leadership towards employee performance through motivation has a positive and significant influence. Transformational leadership towards employee performance through job satisfaction has a positive and significant influence. The results of this research are recommended that the Tranformational leadership has an important role in improving employee performance because a positive influence is able to change the behavior of employees in completing the work even if the employee's work has negative and insignificant influences. Of course, this relies on mastery and trust in the leadership in giving ideas and inspiring to employees in order to do self-reliance without having to wait for instruction from the organization leadership.
\end{abstract}

Keywords: transformational leadership, motivation, job satisfaction, employee performance

DOI: $10.7176 / \mathrm{EJBM} / 12-14-02$

Publication date:May $31^{\text {st }} 2020$

\section{Introduction}

This research is an effort to study about the transformational leadership and hope to give motivation so as to improve the performance of employees after obtaining the desired job satisfaction. However, the fact that the employee has not demonstrated a high existence because the achievement is not maximally, often waiting for encouragement (motivation) from the leadership, and the creativity of work that has not been able to utilize it optimally Thus impacting performance outcomes that have not yet fulfilled the target that the organization wants. Robbins and Judge (2017), that employee performance is performing duties and responsibilities that contribute to the achievement of the work of either the product or service or the task (administration) as most tasks are included in the job description Conventional. Luthans (2011), that motivation is a process that begins with physiological or deficient or psychological needs that activate behavior or encouragement aimed at goals or incentives. Robbins and Judge (2017), that motivation is a process act that explains the intensity of a person, who has the direction and persistence of effort in achieving an organizational goal.

Therefore, the main purpose of the organization in improving performance is that it takes several factors that can give employees satisfaction, because the work done often affects jobs that are like and disliked. While Howard (2009), that work satisfaction as a mixture of the liked and disliked of moods or behaviors of an individual worker on their work schedule, and implying, when an individual is employed may be individuals come by Desires, wants and anticipation that explained their meaning to be there.

Several studies such as Mujkić et al. (2014), Belias and Koustelios (2014), Bayram and Sait Dinç (2015), expressed transformational leadership positively and significantly on employee satisfaction, while Omar and Hussin (2013) Concluded that transformational leadership forces are negative and insignificant to employee satisfaction. Meanwhile, Marnis (2012), Ahmad et al. (2014), Kharabe and Joseph (2016), Manik (2016), Aunjum et al. (2017), Nugroho and Aima (2018) on his results expressed transformational leadership in significant effect on the motivation of employee work. Then Dhermawan et al. (2012) expressed an insignificant motivation against employee satisfaction, this is contrary to the expressed Alif (2015), Ali et al. (2016), Prabowo et al. (2018), Saputra 
and Rahyuda (2018) who expressed significant His influence on job satisfaction. Furthermore Elgelala and Noermijati (2014), Ramlanto et al. (2017), Andriani et al (2018), concluded that the transformational leadership was of significant effect on performance, while the statement of Marnis (2012) was opposite due to the outcome has no significant effect.

However, motivational issues used as employee performance enhancing employees are considered to have important roles in the organization. Because the higher the motivation, the higher the achievement of employees ' work. Marnis Research (2012), Ali et al. (2016) Muchtar (2016), Prabowo et al. (2018), Jarome (2013), Nugroho and Aima (2018), Andriani et al. (2018), Irawan and Yulihasri (2019), Widyaningrum and Rachman (2019) said that the motivation has a significant impact on employee performance. Thus with Atmojo (2012), Tucunan et al. (2014), Tobing and Syaiful (2015), Nugroho and Aima (2018), Acharya et al. (2018) concluded that there was a positive and significant indirect influence between the transformational leadership and employees ' performance through work motivation. While Atmojo (2012), Thamrin (2012), Andreani and Petrik (2016), Naeem and Khanzada (2018), Chandrasekara (2019), concluded that there was an indirect influence and an increase in the transformational leadership style of the employee's performance through Job satisfaction. Therefore, the purpose of this research is to examine the transformational leadership in order to improve employees ' performance at the PU office. Irrigation in Sidoarjo Regency, Indonesia through work motivation and employee satisfaction to be able to produce maximum performance.

\section{Literature review}

\section{Transformational Leadership}

Transformational leadership is described as a form of leadership that is capable of generating or motivating its subordinates, so that the activities undertaken by the employees are able to produce good achievements, at least able to achieve high performance, are considered to exceed what they estimate before. Bass (1985), that transformational leadership enhances the motivation and performance of followers (subordinates) more than transactional leadership, but effective leaders use a combination of both types of leadership. In addition, the Tranformasional leadership style is considered effective in any situation and culture (Bass, 1997). Yukl (2013) states that transformational leadership is a leadership process where followers feel trust, admiration, loyalty, and respect for leaders, and they are motivated to do more than Expected them to do their job. Kondalkar (2007) That transformational leadership is a leader who intellectually stimulates subordinates, excites, arouses and inspires them to do beyond their expectations.

Robbins and Judge (2017), that transformational leaders are leaders who inspire followers to cope with themselves for their interests and who are capable of having profound and remarkable effects on followers. Therefore, effective transformational leadership can be taken on a practical basis based on the transformational leadership model. Bass and Avolio Research (1990), and Bass (1998, 1999), Rafferty and Griffin (2004), Robbins and Judge (2017) equally identically presented a four-dimensional assessment of transformational leadership that is deemed to have a purpose and active in enhancing Employee performance through idealized influence, intellectual stimulation, individual consideration, and inspiration motivation.

\section{Motivation}

Motivation is the act of a process either intrinsic or an individual's extrinsic, giving rise to behavior or an enthusiastic and persistent attitude toward certain activities undertaken in the Organization. Motivation is also interpreted as a driving factor in the behavior of an individual who has the direction and objectives to be achieved. Robbins and Judge (2017), that motivation is a process act that explains the intensity of a person, who has the direction and persistence of effort in achieving an organizational goal. that motivation is a process act that explains the intensity of a person, who has the direction and persistence of effort in achieving an organizational goal. Because motivation not only has the urge to do something (drive) at work but more than that, motivation is expected to fulfill an individual's need for life and according to the objectives achieved. Luthans (2011), that motivation is a process that begins with physiological or deficient or psychological requirements that activate behavior or encouragement aimed at goals or incentives. Hasibuan (2017), that the motivation of work is the giving of the driving force that creates the excitement of one's work so that they will cooperate, work effectively and integrated with all efforts to achieve satisfaction.

Maslow (1943, 1954, 1962), expressed motivation aimed at meeting the needs and satisfaction of people both psychologically and business management known as model hierarchy needs. While this model of motivation needs to have eight stages as a measurement of people's motivation needs, namely: (1) Biological and Physiological needs, (2) Safety needs, (3) Belongingness and Love needs, (4) Esteem needs, (5) Cognitive needs, (6) Aesthetic Needs, (7) Self-Actualization needs, and (8) Transcendence needs (Maslow, 1987).

\section{Job Satisfaction}

Job satisfaction is a positive feeling about work, the outcome of a psychic characteristic evaluation that is pleasing 
and perceived by employees to the work and responsibilities they do in the organization, and its needs have Well fulfilled. Robbins and Judge (2017) that job satisfaction is a positive feeling about the work that results from the characteristic evaluation clearly. Rachman (2017) that job satisfaction has positive and significant effect on employee performance. The higher the level of satisfaction enjoyed by the employee in doing the work, the higher the performance generated by the employee in support of the operations of the Bank Jatim Surabaya. Tirmidhi et al. (2008) That job satisfaction is the level by which people feel positive or negative about their work. This is an emotional attitude or response to one task as well as with the physical and social conditions of the workplace. Howard (2009) that job satisfaction as a mixture of the liked and disliked of moods or behaviors of an individual worker on their work schedule, implying that when an individual is employed maybe the individual comes with a desire, wanting to and the anticipation that explained their meaning to be there. Meanwhile, Luthans (2011) presents five aspects of employee satisfaction used as an indicator: (1) The work itself (related to responsibility, interest and growth); (2) Payment/compensation (Associated with the rewards received in accordance with fair perception); (3) Quality of supervision (3) Quality of supervision (related to technical assistance and social support); (4) Co-worker relationships (dealing harmoniously, socially and respectful); (5) Promotion opportunities (related to career development or job achievement).

\section{Performance}

The performance of employees in the organization or company can be used as a measuring instrument of success in the work or achievement of the results. Dessler (2015) that performance is a working achievement, namely the comparison of the work to the standard set. According to Mathis and Jackson (2008) That performance is essentially what employees do or do not do. Luthans (2011) That performance is the quantity or quality of something produced or services provided by someone who does the job. On the other hand, it is said that the performance management is all activity actions undertaken in order to improve the company's performance including work outcomes or performance of employees and work teams. Robbins and Judge (2017), that performance management is a unique purpose-oriented and continuous way to assess and manage employee performance. Furthermore (Robbins, 2008) suggests 6 performance indicators used as assessment of employee performance, among others: (1) quality, (2) quantity, (3) timeliness, (4) effectiveness, (5) Independence, and (6) Work commitments.

\section{Conceptual Skeleton Model and Hypothesis}

This research explores the level of transformational leadership in public organizations on the outcome of employee performance with motivation and job satisfaction as supporting to produce maximum work in accordance with the organizational objectives as described and the alternative hypothesis formulated as below.

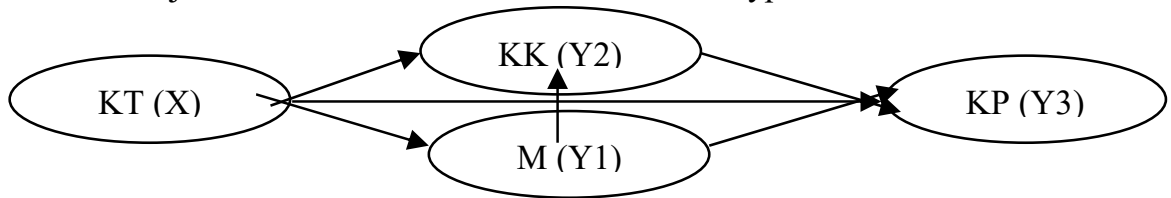

Figure 1. The Model Conceptual Framework Research

Description:

KT : Transformational Leadership

$\mathrm{M}$ : Motivation

KK : Job Satisfaction

KP : Performance of Employees

In accordance with the conceptual frame model, the hypothesis presented in this study is as follows:

1. Transformational leadership has a positive effect on employee motivation.

2. Transformational leadership has a positive effect on employee satisfaction.

3. Motivation has a positive effect on employee satisfaction.

4. Motivation has a positive effect on employee performance.

5. Job satisfaction has a positive effect pda employee performance.

6. Transformational leadership has a positive effect on employee performance.

7. Transformational leadership has a positive effect on employee job satisfaction through motivation.

8. Transformational leadership has a positive effect on employee performance through motivation.

9. Transformational leadership has a positive effect on employee performance through job satisfaction.

\section{Research Methods}

\section{Type and Research Design}

This research is a type of research development or design form that uses a sampling technique that results in variables. Research design is a frame of work in conducting research. This research draft details important 
procedures to obtain the information needed to develop and/or solve research problems (Rachman, 2018). This research draft is a type of exportatory research; This means that the purpose of analyzing the relationship between the construction (variable) or how a construction affects another construct, as the research intends to explain the causal relationship between the construction through hypothesis testing.

\section{Population and Sampling Techniques}

The population is the whole or number of subjects studied but covers all employees in the PU office. The watering of Sidoarjo Regency was 164 employees. While sampling techniques using Stratified random sampling or strata samples are disproportionate because the population and samples for employees in this research are heterogeneous and limited to a large number of populations. Sampling techniques used in calculating the number of variable indicators observed with calculations between 5 - 10 for the data of the observed indicators (Hair et al. in Rachman, 2018). The indicator instrument uses a total of 23 observation indicators with four investigated variables, while determining the indicator of an observation variable using the number 7; The reason is that the large sample used can be close to the population, which is 161 respondents from 164 employees, in addition it can produce goodness of fit and according to the framework of the model formed (Rachman, 2018).

\section{Data Analysis Techniques}

For its analytical techniques using the SEM analysis that tests the latent construct models formed from indicators, and carried out through testing instruments. While this measurement model (external load) is the reliability and testing of the konfirmatory factor by testing each of the indicators or reflective indicator models because it is formed and affects latent construcs.

\section{The Results}

\section{Structural Equation Modeling (SEM) Analysis}

Before the statistical test, there is a test of the observed indicator using the measurement process model or confirmatory factor analysis (CFA) test. The result of the confirmatory factor analysis model described by the employee's performance in the six indicators is capable of forming structural equation modeling in this research well, the results are positive and significant so that the results support or accept the concept of theory used in this research as structural modeling.

\section{Evaluation of Goodness of Fit Index on SEM}

Structural Equation Modeling (SEM) analysis is used to figure out structural relationships between variables. Structural relationships between variables are tested for compliance with the Goodness of Fit Index. The results of structural equation modeling analysis that has been conducted analysis in this research are shown in the figure below:

Figure 2

Model influence the performance of Employees of the Office of Irrigation works of the District, Sidoarjo

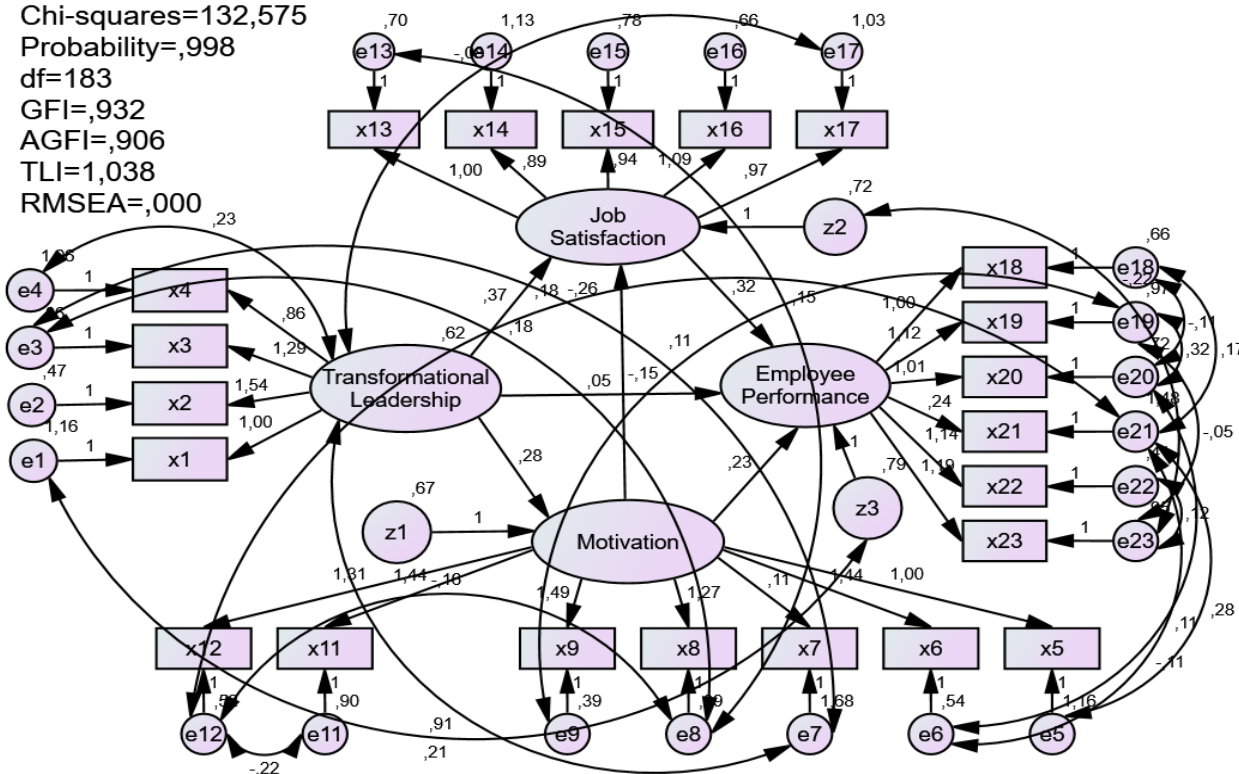

Based on figure 2. show the results of the analysis of the SEM model indicated by the value of Goodness of Fit in table below; 
Table 1.

The analysis of the Goodness of Fit of the Modified SEM

\begin{tabular}{|l|ccc|}
\hline Goodness of Fit Indices & $\begin{array}{c}\text { Analysis Result } \\
\text { df. } 183\end{array}$ & Cut-off Value & Evaluation of the Model \\
\hline Chi-Square & 132,575 & Expected that small or $<3$ & Not Good \\
CMIN/DF & 0,724 & $\leq 2,00$ & Good \\
Significance Probability & 0,998 & $\geq 0,05$ & Good \\
RMSEA & 0,000 & $\leq 0,08$ & Good \\
GFI & 0,932 & $\geq 0,90$ & Good \\
AGFI & 0,906 & $\geq 0,90$ & Good \\
TLI & 1,038 & $\geq 0,95$ & Good \\
CFI & 1,000 & $\geq 0,95$ & Good \\
NFI & 0,931 & $\geq 0,90$ & Good \\
\hline
\end{tabular}

Source: Primary data processed researchers, 2019

The results of data processing analysis are seen that all the construction used to form a research model, in the process of the relationship analysis between the construction, produced has fulfilled the criteria of goodness of fit indices that has been designated as a good structural model. Thus the matching model predicted with the observation values is quite fulfilling for the suitability of the formed model.

Test goodness of fit indices on the structural model indicating the resulting data is fit because it meets all the required criteria, namely fit $\mathrm{RMSEA}$ value $=0.000 \leq 0.080$; Fit GFI value $=0.932 \geq 0.90$; Fit Value $\mathrm{AGFI}=0.906$ $\geq 0.90$; Fit TLI value $=1.038 \geq 0.95$; Fit value $\mathrm{CFI}=1.000 \geq 0.986$; And the fit NFI value $=0.931 \geq 0.90$; And the level of Significance Probability $=0.998 \geq 0.05$ and the results expressed well. Similarly, cmin/DF produces a good assessment of $0.724<2$, so has fulfilled the criteria that generate smaller than the specified (Cut-off Value) requirement, but only in the Chi-Square coefficient which has a value of $132.575>3$ Nevertheless the SEM model in the analysis is not very influential in the modeling in this study. Thus the structural model is used, and analyzed in this study has been received because there is no difference between the sample covariant matrix with an estimate of the population covariant matrix, so that the model used as research is acceptable and the next step analyzing the estimate parameters.

\section{Hypothesis Test}

This hypothesis test is performed to determine the influence or absence of an exogenous variable on the endogenous variable. This hypothesis can be acceptable if the resulting probability value is $\mathrm{p} \leq 0.05$. The results of this hypothesis test can be seen in the table as follows:

Tabel 2.

Standardized Regression Weights Analysis

\begin{tabular}{|lll|rrrrr|}
\hline & Direct effect & Estimate & S.E. & C.R. & P & Depc. \\
\hline Motivation & $<---$ & Transformasional_Leadership &, 257 &, 100 & 2,784 &, 005 & Sig. \\
Job_Satisfaction & $<---$ & Transformasional_Leadership &, 329 &, 109 & 3,439 &, 000 & Sig. \\
Job_Satisfaction & $<---$ & Motivation &,- 139 &, 094 & $-1,560$ &, 119 & Nonsig. \\
Employee's_Performance & $<---$ & Motivation &, 200 &, 100 & 2,263 &, 024 & Sig. \\
Employee's_Performance & $<---$ & Job_Satisfaction &, 302 &, 106 & 3,054 &, 002 & Sig. \\
Employee's_Performance & $<---$ & Transformasional_Leadership &, 040 &, 108 & 0,451 &, 652 & Nonsig. \\
\hline
\end{tabular}

Source: Primary data processed researchers, 2019

Based on table 2. Shows the results of the Standardized Regression Weights analysis which has a relationship between the exogenous and endogenous variables directly as the following:

1. Transformsional leadership has a significant and positive impact on employee motivation by 0.257 estimate and probability of 0.005 or $\mathrm{P}<0.05$; Results are received and the effect is positive in direction with regression weight.

2. Transformsional leadership has a positive and significant impact on employee job satisfaction with a estimate of 0.329 and probability of 0.000 or $\mathrm{P}$ of $<0.05$; the results are received and the effect is positive in the direction of regression weight. 3 . The motivation has negative and insignificant effect on employee job satisfaction with estimate of -0.139 and probability of 0.119 or $p>0.05$; The result is rejected and negative Regression weight.

4. Motivation has positive and significant impact on the employee's performance with estimate of 0.200 and probability of 0.024 or $\mathrm{P}$ of $<0.05$; Results are received and the effect is positive in direction with regression weight.

5. Job satisfaction positively and significantly affect the employee's performance with estimate of 0.302 and 
probability, 0.002 or $\mathrm{P}<0.05$; results received and positive influence in the direction of regression weight.

6. Transformsional leadership has a positive and insignificant impact on employees performance with estimate of 0.040 and probability of 0.652 or $p>0.05$; the results were rejected. and positive influences are proportional to regression weight.

Further analysis results of the Standardized Regression Weights that have a relationship between the exogenous and endogenous construction which is directly presented in the table below;

Tabel 3.

Standardized Indirect Effects Analysis

\begin{tabular}{|l|rrrr|}
\hline Indirect effects & Transformasional_Leadership & Job_Motivation & Job_Satisfaction Employee's_Performance \\
\hline Job_Motivation &, 000 &, 000 &, 000 &, 000 \\
Job_Satisfaction &,- 036 &, 000 &, 000 &, 000 \\
Job_Satisfaction &, 140 &,- 042 &, 000 &, 000 \\
\hline
\end{tabular}

Source: Primary data processed researchers, 2019

Based on table 3. Shows the results of the Standardized Indirect Effects Analysis of the inter-construction directly as follows:

7. Transformational leadership is negatively influential and insignificant to employee job satisfaction through motivation with standardized of estimate-0.036; Result is rejected.

8. Transformational leadership is negatively and significantly influential on the employee's performance through motivation with standardized of estimate-0.042; The results received.

9. Transformational leadership has positive and significant effect on employee performance through work satisfaction with standardized of estimate 0.140 ; The results received.

\section{Discussion}

The analysis of the structural model discussed has a relationship between the construction as follows;

1. Influence of transformational leadership on motivation

The result of the analysis of transformational leadership to the motivation has a positive and significant influence because of the achievement of employees ' work according to what is desired by the organization of the Office of PU Irrigation Department in Sidoarjo Regency. The result of this positive influence indicates that the leadership role in the organization is important because it always supports employee activity. This means that a high level of motivation is a significant contribution because the important role of leadership behavior gets the trust of employees over the type of transformational leadership, so as to produce a positive and significant influence on Employee motivation. The results of this research are in line with the research results of Marnis (2012), Ahmad et al. (2014), Kharabe and Joseph (2016), Manik (2016), Aunjum et al. (2017), Nugroho and Aima (2018).

2. Influence of transformational leadership on job satisfaction

The results of a transformational leadership relationship to job satisfaction have a positive and significant influence as the achievement of employee work shows that leadership is conducted by transformational way to Employees in the organization are able to give self-satisfaction the officers themselves both materically and non materil, because the leadership always support the activities undertaken by the officers, and believe in the work achieved by the employees so that the achievement of the results This satisfactory work is capable of receiving a response that can give satisfaction to the leadership of the organization. This means that the high level of job satisfaction is able to contribute significantly because of the important role of leadership behavior that gets the trust of employees for the transformational leadership, so as to produce positive influence and To employee work satisfaction. The results of this research in line with the results of the research conducted Mujkić et al. (2014), Belias and Koustelios (2014), Bayram and Sait Dinç (2015), and rejected the research results of Omar and Hussin (2013) stating the style of transformational leadership Significant negative impact on employee work satisfaction.

3. Influence of motivation on job satisfaction

The results of analysis of motivation relationship to work satisfaction have negative and insignificant influence because a achievement of work results show if motivation used as pusher for activity in solving job, this Can not afford to give the employee self-satisfaction on the organization. Because the leadership is less responding to the activities undertaken by the officers, so that the trust given to employees in the achievement of work results can not satisfy the organization. This means that a high level of work motivation has not been able to contribute significantly because the important role of the leadership is especially the transformation has not been able to contribute to motivate employees to produce high job satisfaction., so it is still needed more serious interaction in supporting employee motivation and confidence in the personnel to be able to give high job satisfaction. Because of the factors of motivation needs that have to get repon from the leadership oragnization. The results of this research are not in line with the research results of Alif (2015), Ali et al. (2016), Prabowo et al. (2018), Saputra and Rahyuda (2018) who expressed significant influence on job satisfaction, otherwise the results of this research in line With the research of Dhermawan et al. (2012) Because of insignificant influence on employee satisfaction. 
4. Influence of motivation on employee performance

The results of analysis of the motivation relationship to the employee's performance have a positive and significant influence as the achievement of the results shows that the motivation made with the improvement of employee work in the organization is able to give Significant results in the officer itself, because the leadership always encourages and supports the activities of the officers, believes and has confidence that employees ' work activities have a high quality and quantity in the achievement of work outcomes Employees produce satisfactory results so that they get a good response from the organization leadership. It means that the high level of motivation is able to contribute significantly because the important role as a model always gained the trust of the employees in the high achievement also so as to meet the satisfactory needs in Organization, specialized in self-employed personnel. The results of this research are in line with the research results of Marnis (2012), Ali et al. (2016) Muchtar (2016), Prabowo et al. (2018), Jarome (2013), Nugroho and Aima (2018), Andriani et al. (2018), Irawan and Yulihasri (2019), Widyaningrum and Rachman (2019).

5. Influence of job satisfaction on employee performance

The results of the analysis of job satisfaction relationship to the employee's performance have a positive and significant influence because the achievement of the results shows that the job satisfaction can have positive impact for the organization. Therefore, the leader of the organization has always believed in employees in conducting their high activity and integrity quickly in completing a job because the leadership always encourages and supports employees ' activities, believes and has Belief that employees ' work activities during this time have high quality and quantity in achieving their work so as to produce satisfactory results in the organization. This means that the high level of job satisfaction is able to contribute significantly to the performance because the important role of the leader always gained the trust from the employees so as to meet the satisfying needs of the organization, the employee's special self Own. The results of this research are in line with the research results of Thamrin (2012), Lilawati and Mashari (2017), Rachman (2017), Prabowo et al. (2018).

6. Influence of transformational leadership on employee performance

The results of a transformational leadership relationship to the employee's performance had a positive and insignificant influence as the achievement of the work showed that the leadership was conducted by transformational means to employees. Very supportive and able to interact well, the expectation of achievement is able to improve the results of high performance because the leadership always support and respond to every activity conducted by officers, and leaders who always trust with the results of work achieved by the employees can contribute, in fact turned out because the achievement of the work desired the organization has not been able to give high satisfaction to the organization. This means that high transformational leadership is expected to contribute significantly to employees ' performance but has not been able to produce the best for the organization. Therefore, the importance of transformational leadership to get the trust of the employees because each factor of transformational leadership is still able to play a role in improving employee performance so that it needs to be reevaluation of Inability to improve its performance. The results of this study were not in line with the research results of Prajogo (2013), Elgelala and Noermijati (2014), Tucunan et al. (2014), Ramlanto et al. (2017), Andreani and Petrik (2016), Nugroho and Aima (2018), Andriani et al. (2018), and received Marnis Research (2012) because it has no significant influence.

7. Influence of transformational leadership on employees' work satisfaction through motivation

The results of a transformational leadership relationship to employee work satisfaction through motivation have negative and insignificant influence as the achievement of work results shows that leadership is done by In order to interact less supportive in motivating officers so that hope for its achievement has not been able to improve the results of high performance. It means that the transformational leadership that is done is too low and has not been able to contribute significantly to the job satisfaction because of the important role of leadership that is transformational and need to respond to employees well so that Leadership with transformational type can gain trust from employees, let alone the leadership always provide support and motivate employees to produce work that satisfies the organization and self-employee itself so that The success of positive and significant influence on job satisfaction can be achieved in accordance with organizational objectives. The results of this study were not in line with the research results of Amaliyah et al. (2014).

8. Influence of transformational leadership on employees' performance through motivation

The results of a transformational leadership relationship to employees ' performance through motivation have a positive and significant influence as the achievement of high employment results signifies that leadership is done by The transformation of the employees is very supportive so that the interaction carried out by the leadership can bring change and improvement in the performance of employees able to produce high performance because the employee response to the type of transformational leadership Considered to be able to provide social needs to employees, so that the trust built by the leader in motivating the work of employees can create the work achieved by employees and able to make a satisfactory contribution to the Organization so that Motivating expectations in achieving high performance can be achieved according to organizational objectives. This means that high transformational leadership is able to contribute significantly to employees ' performance because leaders always 
motivate employees who hope their work is achieved and positively influence. Therefore, the leader must be proactive in motivating employees, the reason, the work of employees who are expected to produce positive and significant influence on employee performance because it is supported with high motivation. The results of this study were not in line with the research results of Atmojo (2012), Tucunan et al. (2014), Tobing and Syaiful (2015), Manik (2016), Nugroho and Aima (2018), Acharya et al. (2018).

9. Influence of transformational leadership on employees' performance through job satisfaction

The results of the transformation of transformational leadership to employees ' performance through job satisfaction have a positive and significant influence as the achievement of work results shows that the leadership done with the type Employees, the officers themselves are able to interact with the leadership in the work activities well done, so that the high performance of employees get a response from the leadership, and the leadership is more confident with Work achieved by the employees for being able to contribute to the achievement of satisfactory work. This means that high transformational leadership is able to contribute significantly to employees ' performance because of the crucial role of a transformational leader who is able to produce positive and significant impact on performance Supported by high job satisfaction. The results of this research are in line with the research results of Atmojo (2012), Thamrin (2012), Marnis (2012), Andreani and Petrik (2016), Naeem and Khanzada (2018), Bernanthos (2018), Chandrasekara (2019).

\section{Conclusion}

The analysis and discussion of the structural model in this study concluded that transformational leadership was positively influential in employee motivation. The result of this positive influence is able to bring change in employee motivation improvement. The higher the type of transformational leadership conducted by the officers, the higher the work activity achieved by the employees so as to create motivation. Whereas transformational leadership also has a positive influence on employee satisfaction. Because of this positive influence brings significant changes in contributing to the organization. In addition, the transformational leadership conducted by the leadership in the management of work activities also has a positive influence on employee performance. But the result is not significant, because the role of leadership that is acting as an officer is not functioning properly, and unable to change the behavior of employees in improving their work. Resulting in a decrease in the role of transformational leadership applied.

In addition, motivation also as a spill in improving employee performance because it is able to positively influence. It is demonstrated that there is a significant change and improvement over the employee's work, and the higher the urge to motivate the employees, the higher the results of the employee's performance. But these results, lack of support for the satisfaction of the work that employees achieve because the motivation has a negative influence on employee satisfaction work. The result of this negative influence indicates that employees have not gained comfort in working despite having gained a high boost or motivation from the leadership. So it is necessary to be evaluated again to change the employee's view. While the satisfaction of the work itself has a positive and significant influence on employee performance. The result of this positive influence means that employees are comfortable with the work done so that the work satisfaction produced is able to improve the work in accordance with the desired organization.

Other findings that support transformational leadership in improving Pagawai performance are job satisfaction. Due to the positive and significant influence of transformational leadership on employees 'performance through job satisfaction, demonstrated leadership role is able to contribute so that the achievement of the desired work is in accordance with Organizational objectives. In addition, motivation also has a positive influence as mediation that supports the transformational leadership in the improvement of employee performance because the employee response built by the leadership is able to motivate the employee so that it can produce The expected performance of the organization. However, this motivation is not able to contribute to the satisfaction of employees ' work despite the transformational leadership type that is performed as a role model in motivating employees. Negative and insignificant influence on employee satisfaction through motivation shows if leadership by transformational Way is not able to change employee behavior in giving job satisfaction although motivation is always done And persutative, so that the leadership need to be self-conscious and aware of these conditions, and the leadership needs to take an action and solution that is in accordance with the complaints faced by employees during work activities, especially the workload provided Employees.

\section{Recommendations}

The results of the transformational leadership analysis used to change and improve employee motivation in working activities as well as to provide job satisfaction to employees has been able to produce positive and significant influence directly because Supported by several motivational indicators and a work satisfaction indicator that has a significant influence, so the expectation of the Organization in support of organizational objectives can be achieved well so it is necessary to get serious attention from the leadership Organization. But on the other hand, the expected performance can achieve maximum results, otherwise obtained, still lacks support of 
the transformation leadership model applied because the result is negatively influential so that it becomes a statement in the Organizations despite significant results. Therefore, the organization's leadership needs to do an approach to the problems that are a road to the employees. While the success of the transformation leadership that has an indirect and positive influence on the performance of employees both through work satisfaction and motivation can be improved so that the results are always significant.

Unlike the work satisfaction whose influence through motivation results in negative and insignificant influence for transformational leadership. It is certainly related to some indicators between motivation and satisfaction of work that does not have an identical relationship in fulfilling organizational objectives so as not to produce positive and significant influence in supporting models Transformasional leadership. Therefore, it is necessary to reconsider the relation to the relationship between the two Construk in order to fulfill the objectives of the Organization.

\section{Acknowledgements}

We convey many thanks to the institutions of education University of PGRI Adi Buana Surabaya, Indonesia in particular LPPM (institute for research and Community development) has been providing assistance, both material and non material in support of improving the quality of lecturer with give out the financing of faculty research. In addition, we are also grateful to the Rector, the Dekan of the Faculty of Economics and Business, and some administrative staff of the University who have helped the implementation of the research we do in a institutions of government, particularly civil water engineering city of Sidoarjo, East Java - Indonesia.

\section{REFERENCE}

Acharya Nirmal Acharya, Abhishek Sharma, Dave Aum Nitishbhai, and Avijit Chowdhury. 2018. The Impact of Transformational Leadership on Motivation and Performance of the Followers. Elk Asia Pacific Journal of Leadership and Innovation Management. Volume 4 Issue 2. 2018. ISSN 2394-0417 (Online); EAPJLIM/issn. 2394-0417/2015.

Ahmad, Farid, Tasawar Abbas2, Shahid Latif2, Abdul Rasheed. 2014. Impact of Transformational Leadership on Employee Motivation in Telecommunication Sector. Journal of Management Policies and Practices. June 2014, Vol. 2, No. 2, pp. 11-25.

Ali, Amjad, Zulfiqar Ali, Li Zhong Bin, and Huang Jian Piang. 2016. The Impact of Motivation on the Employee Performance and Job Satisfaction in IT Park (Software House) Sector of Peshawar, Pakistan. International Journal of Academic Research in Business and Social Sciences. 2016, Vol. 6, No. 9 ISSN: 2222-6990.

Alif, Abda. 2015. Pengaruh Motivasi Kerja, Pengembangan Karir, Lingkungan Kerja Terhadap Perilaku Kewarganegaraan Organisasi (OCB) Dengan Kepuasan Kerja Sebagai Variabel Intervening. Jurnal MIX, Volume VI, No. 2, Juni 2015.

Amaliyah, Farisa Nuril, Bambang Swasto dan Heru Susilo. 2014. Pengruh Gaya Kepemimpinan Transformasional Terhadap Kepuasan Kerja Karyawan Dengan Motivasi Kerja Karyawan Sebagai Variabel Mediasi (Penelitian pada Karyawan PT. Bank Rakyat Indonesia (persero), Tbk.Kantor Cabang Blitar). Jurnal Administrasi Bisnis (JAB). Vol. 14 No. 1 September 2014.

Andriani, Septi, Nila Kesumawati, and Muhammad Kristiawan. 2018. The Influence of The Transformational Leadership and Work Motivation On Teachers Performance. International Journal of Scientific \& Technology Research. Volume 7, Issue 7, July 2018.

Andreani, Fransisca and Petrik, Abelio. 2016. Employee Performance as the Impact of Transformational Leadership and Job Satisfaction in PT. Anugerah Baru Denpasar. JMK, Vol. 18, No. 1, March 2016, $25-32$. ISSN 2338-8234. DOI: 10.9744/jmk.18.1.25-32.

Armstrong, Michael. 2014. Handbook of Human Resource Management Practice. Thirteenth edition. London, United Kingdom: Kogan Page Limited.

Aunjum, Adeel Hussain, Ghulam Abbas, and Muhammad Sajid. 2017. Transformational Leadership and Employee Motivation in Banking Sector of Pakistan. Advances in Economics and Business. 5(9): 487-494, 2017. DOI: 10.13189/aeb.2017.050901.

Atmojo, Marnis. 2012. The Influence of Transformational Leadership on Job Satisfaction, Organizational Commitment, and Employee Performance. International Research Journal of Business Studies. vol. V no. 02. pp. 113-128. ISSN: 2089-6271.

Bass, Bernard M. 1985. Model of Transformational Leadership. In T.F. Mech \& G.B. McCabe (Eds.), Leadership and Academic Librarians. pp. 66-82.

Bass, Bernard M. 1997. Does the Transactional/Transformational Leadership Paradigm Transcend Organizational and National Boundaries? American Psychologist, 52, 130-139.

Bass, Bernard.M. 1998. Transformational leadership: Industrial, military and educational impact. Mahwah, NJ: Lawrence Erlbaum Associates Inc.

Bass, Bernard M. 1999. Two Decades of Research and Development in Transformational Leadership. European 
Journal of Work and Organizational Psychology. 8 (1), 9-32.

Bass, B. M., \& Avolio, B. J. 1990. The Implications of Transactional and Transformational Leadership for Individual, Team, Organizational Development. Research in Organizational Change and Development, 4, 231-272.

Bayram, Hamidullah and Sait Dinç. 2015. Role of Transformational Leadership on Employee's Job Satisfaction: The Case of Private Universities in Bosnia and Herzegovina. European Researcher, April 2015, Vol. (93), Is. 4.

Belias, Dimitrios and Koustelios, thanasios. 2014. Transformational Leadership and Job Satisfaction in the Banking Sector: A Review. International Review of Management and Marketing. Vol. 4, No. 3, 2014, pp.187200. ISSN: 2146-4405.

Bernanthos, Bambang. 2018. The Direct and Indirect Influence of Leadership, Motivation and Job Satisfaction Against Employees' Performance. European Research Studies Journal. Volume XXI, Issue 2, pp. 236-243. 2018.

Chandrasekara, WS. 2019. The Effect of Leadership Style on Employees' Job Satisfaction and Job Performance: a Case of Apparel Manufacturing Company in Sri Lanka. International Journal of Economics, Commerce and Management. Vol. VII, Issue 7, July 2019. ISSN 23480386.

Dessler, Gary. 2015. Human Resource Management. Thirteenth Edition. New Jersey: Pearson Education, Inc.

Dhermawan, Anak Agung Ngurah Bagus, I Gde Adnyana Sudibya, dan I Wayan Mudiartha Utama. 2012. Jurnal Manajemen, Strategi Bisnis, dan Kewirausahaan. Vol. 6, No. 2. Hal.173-184. Agustus 2012.

Elgelala, Kamel Saleh Khalifa dan Noermijati. 2014. The Influences of Transformational Leaderships on Employees Performance (A Study of the Economics and Business Faculty Employee at University of Muhammadiyah Malang). Asia-Pacific Management and Business Application. Vol.3 (1) 48 - 66. ISSN: 2252-8997.

Grant, Adam M. 2012. Leading with Meaning: Beneficiary Contact, Prosocial Impact, and the Performance Effects of Transformational Leadership. Academy of Management Journal. Vol. 55, No. 2, 458-47.

Hair, J.F. Jr., RE. Anderson, R.L., Tatham and W.C. Black, 2014. Multivariate Data Analysis with Readings. Englewood Cliffs, NJ. New Jersey: Prentice Hall Inc.

Hasibuan, Malayu S.P. 2017. Manajemen Sumber Daya Manusia. (Edisi Revisi). Jakarta: Bumi Aksara.

Howard Baldwin, Tonia Toinette. 2009. Administrator Job Satisfaction in Higher Education. Dissertation. Auburn, Alabama.

Irawan, Wira and Yulihasri. 2019. the Effect of Adversity Quotient, Motivation and Discipline of the Employee Performance of PT. PLN (Persero) Region West Sumatra Padang Indonesia. International Journal of Innovative Science and Research Technology. Volume 4, Issue 4, April - 2019. ISSN No:-2456-2165.

Kharabe, Rahul and Joseph, Jonathan. 2016. Transformational Leadership: Its Influence on Employee Motivation. International Journal of Commerce and Management Studies (IJCAMS), ISSN 2456-3684. Vol.01, No.02, 2016.

Jerome, Nyameh. 2013. Application of the Maslow's hierarchy of need theory; impacts and implications on organizational culture, human resource and employee's performance. International Journal of Business and Management Invention. Volume 2 Issue 3. March. 2013. PP.39-45.

Donatus Adi Kurniawan*, Guswandi \& Akhmad Sodikin, The Effect of Competence and Motivation on Employee Performance Through Employees Capabilitieson PT. BINASINAR AMITY. International Journal of Research Science \& Management. 5(5): May, 2018. ISSN: 2349-5197.

Kondalkar, V.G. 2007. Organizational Behviour. New Delhi: New Age International (P) Limited, Publishers.

Luthans, Fred. 2011. Organizational Behavior: An Evidence Based Approach, Twelfth Edition, New York: McGraw-Hill/Irwin.

Manik, Ester. 2016. he Influence of Transformational Leadership on Achievement Motivation and Organizational Climate and Employee Performance. International Journal of Academic Research in Business and Social Sciences. Vol. 6, No. 12. ISSN: 2222-6990.

Marnis. 2012. Transformational leadership in thr efforts of increasing motivation, performance, and job satisfaction at PT. Bank Mandiri Tbk at Pekanbaru. Journal of Economics, Business, and Accountancy Ventura. Volume 15, No. 2, August 2012, pages $273-288$.

Maslow, A. Harold. 1943. A Theory of Human Motivation. Psychological Review, 50, 370-396. Retrieved June 2001, from http://psychclassics.yorku.ca/ Maslow/ motivation.htm.

Maslow, A. Harold. 1954. Motivation and Personality. New York: Harper. •

Maslow, A. H. 1962. Some Basic Propositions of a Growth and Self-Actualization Psychology. In A. H. Maslow, Toward a Psychology of Being. (pp. 177-200). Princeton, NJ: Van Nostrand.

Maslow, A. H. 1970a. Motivation and Personality. New York: Harper \& Row.

Maslow, A. H. 1970b. Religions, Values, and Peak Experiences. New York: Penguin. (Original work published 1964). 
Maslow, A. Harold. 1971. The Farther Reaches of Human Nature. New York: The Viking Press.

Maslow, A. H. 1987. Motivation and personality (3rd ed.). Delhi, India: Pearson Education.

Mathis, R.L, Jackson, J.H. 2008. Human Resource Management. $13^{\text {th }}$ Edition. Boston, USA: South-Western.

Mondy, R. Wayne dan Martocchio, Joseph J. 2016. Human Resource Management. Fourteenth Edition, Global Edition. England: Pearson Education Limited.

Mujkić, Alisa, Zijada Rahimić, Dževad Šehić, Jasmin Jusić. 2014. Transformational Leadership and Employee Satisfaction. Ekonomski Vjesnik/Econviews. God. XXVII, BR. 2/2014. str. 259-270

Naeem, Shahzad and Khanzada, Benish. 2018. Role of Transformational Leadership in Employee's Performance with Mediating Role of Job Satisfaction in Health Sector. Journal of Health Education Research \& Development. 2018, 6:1. ISSN: 2380-5439. DOI: 10.4172/2380-5439.1000245.

Nugroho, Ganjar Satrio dan Aima, M. Havidz. 2018. Influences of Transformational Leadership and Compensation To Employee Performance On Their Motivation And The Implementation At X Institution. International Journal of Scientific and Research Publications, Volume 8, Issue 12, December 2018352 ISSN 2250-3153.

Omar, W.A. Wan dan Hussin, Fauzi. 2013. Transformational Leadership Style and Job Satisfaction Relationship: A Study of Structural Equation Modeling (SEM). International Journal of Academic Research in Business and Social Sciences. February 2013, Vol. 3, No. 2 ISSN: 2222-6990.

Prabowo, Thoni Setyo, Noermijati and Dodi Wirawan Irawanto. 2018. The Influence of Transformational Leadership and Work Motivation on Employee Performance Mediated by Job Satisfaction. Journal of Applied Management (JAM). Volume 16 Number 1, March 2018.

Prajogo, Wisnu. 2013. Pengaruh Dimensi-dimensi Kepemimpinan Transformasional dan Kepemimpinan Transaksional pada Kinerja. MODUS. Vol. 25 (2):125-138, ISSN 0852-1875.

Rachman, Mochammad Munir. 2019. Aplikasi Komputer Statistik: Sebagai Pendukung Untuk Analisis Data Penelitian. Edisi Revisi. Surabaya: Penerbit Unipress, Universitas PGRI Adi Buana Surabaya, Indonesia.

Rachman, Mochammad Munir. 2018. Metodologi Penelitian, Edisi Pertama. Cetakan Kedua. Surabaya: Penerbit Unipress, Universitas PGRI Adi Buana Surabaya, Indonesia.

Rachman, Mochammad Munir. 2017. The Influence of Work Culture on Job Satisfaction and Performance: A Study on the Employees of the Bank Jatim in Surabaya, East Java, Indonesia. European Journal of Business and Management (IISTE). Vol.9, No.26.pp.30-39. ISSN 2222-1905 (Paper) ISSN 2222-2839 (Online).

Rafferty, Alannah E. and Griffin, Mark A. 2004. Dimensions of Transformational Leadership: Conceptual and Empirical Extensions. The Leadership Quarterly. 15 (2004) 329-354. doi:10.1016/j.leaqua.2004.02.009. 2004 Elsevier Inc.

Ramlanto, Soewarto Hadhienata, and Widodo Sunaryo. 2017. The Correlation between Organizational Culture, Transformational Leadership and Work Motivation to Teachers' Performance. International Journal of Managerial Studies and Research (IJMSR). Volume 5, Issue 4, April 2017, PP 22-28.

Robbins, Stephen. P. 2008. Perilaku Organisasi. Edisi Bahasa Indonesia. Jakarta: PT Indeks Kelompok Gamedia.

Robbins, Stephen P. dan Judge, Timothy A. 2017. Organizational Behavior. $18^{\text {th }}$ Edition. England: Pearson Education. ISBN-13: 978-0134729329.

Saputra, Anak Agung Gede Dharma dan Rahyuda, Agoes Ganesha Rahyuda, 2018. Pengaruh Kepemimpinan, Motivasi, Lingkungan Kerja Terhadap Kepuasan Kerja Pegawai Kontrak Sekretariat Kantor Walikota Denpasar. E-Jurnal Manajemen Unud. Vol. 7, No. 5, 2018: 2565-2591. DOI: https://doi.org/0.24843/EJMUNUD.2018.v7.i05.p11. ISSN: 2302-8912.

Thamrin, H.M. 2012. The Influence of Transformational Leadership and Organizational Commitment on Job Satisfaction and Employee Performance. International Journal of Innovation, Management and Technology. Vol. 3, No. 5, October 2012.

Tirmizi, M.A., Malik, M.I. \& Mahmood-ul-Hasan. 2008. Measuring Satisfaction: An Investigation Regarding age, Tenure and Job Satisfaction of White Collar Employees. Available at: http://icbm.bangkok.googlepages.com/3. Muhammad. Ali.Tirmizi.PAR.pdf. Accessed on 20 April, 2009.

Tobing, Diana Sulianti K. dan Muh. Syaiful. 2015. The Influence of Transformational Leadership, Organizational Culture, and Work Motivation on Employee Performance at the State Property Service Office and Auction in East Java Province. International Journal of Business and Commerce. Vol. 5, No.06: [37-48]. ISSN: $2225-$ 2436.

Tucunan, Roy Johan Agung, Wayan Gede Supartha, I Gede Riana3. 2014. pengaruh kepemimpinan transformasional terhadap motivasi dan kinerja karyawan. (Sudi Kasus Pada PT. Pandawa). E-Jurnal Ekonomi dan Bisnis Universitas Udayana. 3.9 (2014) :533-550.

Ward, David Marta Lasem. 2009. An Overview of Needs Theories behind Consumerism. Journal of Applied Economic Sciences. Volume IV. Issue 1(7)/Spring 2009.

Widyaninfrum, M. Enny and Rachman, Mochammad Munir. 2019. The Influence of the Work Environment, Organizational Commitment and Organizational Citizenship Behavior on Employee Performance and 
Motivation as Intervening (Studies in the Matahari Department Store Tbk. Tunjungan Plaza in Surabaya, Indonesia). European Journal of Business and Management (IISTE). Vol.11, No.35.pp.60-68. ISSN 22221905 (Paper) ISSN 2222-2839 (Online).

Yukl, Gary. 2013. Leadership in Organizations. Eighth Edition. New Jersey: Pearson Education, Inc. 